\title{
Migrant Children's Rights to Health and Rehabilitation: A Primer for US Social Workers
}

\author{
S. Megan Berthold ${ }^{1} \cdot$ Kathryn Libal $^{1,2}$
}

Published online: 29 April 2016

(C) Springer International Publishing 2016

\begin{abstract}
This article addresses the rights of migrant children to rehabilitation, health, and well-being, particularly when held in US detention. We provide contextual background on recent increases in irregular migration of children and youth to the United States from Latin America, highlighting how detention practices in the country violate domestic and international legal standards. We introduce key international human rights instruments and provisions related to the rights of migrant children and elaborate on the emergent meaning of a right to rehabilitation, which should be understood as an aspect of children's right to the highest attainable standard of physical and mental health. The right to rehabilitation for migrant children who have experienced trauma and violence is a critical obligation that has implications for federal, state, and local governments in the United States, as well as, importantly, the social work profession.
\end{abstract}

Keywords Child $\cdot$ Migrant $\cdot$ Human rights $\cdot$ Health . Children's rights

S. Megan Berthold

megan.berthold@uconn.edu

1 University of Connecticut School of Social Work, 1798 Asylum Ave., West Hartford, CT 06117, USA

2 Human Rights Institute, Thomas J. Dodd Research Center, University of Connecticut, 405 Babbidge Road, U-1205, Storrs, CT 06269, USA

\section{Introduction}

"[I]mmigration policies should never be enforced at the expense of a child's enjoyment of all his/her rights and best interests, and ...the enforcement of migration policies must involve the oversight of agencies specializing in children's rights."

- François Crépeau, Special Rapporteur on the Rights of Migrants (Committee on the Rights of the Child 2012, par. 12)

For the past several years, the United States has experienced a significant increase in the numbers of migrant children from El Salvador, Guatemala, Honduras, and Mexico crossing the US-Mexico border. These children flee for a number of reasons, including gang and other societal violence, child abuse or other harms requiring international protection, or seeking economic opportunities (UNCHR 2014a). In summer 2014, this culminated in an unprecedented number of Central American children entering into the United States to face detention and/or deportation - a phenomenon that caught the attention of human rights activists, the media, politicians, the general public, and, increasingly, social work practitioners and educators (Wilson 2014; Zayas 2015).

The large-scale influx of migrant children, many of whom were unaccompanied by adults, was cast as a humanitarian crisis in the media. The United Nations High Commissioner for Refugees (2014) surveyed 404 unaccompanied children from El Salvador, Guatemala, Honduras, and Mexico and found that more than $50 \%$ might meet the criteria required for refugee status (including $72 \%$ of those from El Salvador, $57 \%$ of those from Honduras, and $38 \%$ of those from Guatemala). Refugee status would afford children more stable legal standing, with accompanying rights and benefits in the United States. Given the possibility that they might be in 
danger if they are deported, these children should be afforded a fair and complete review of their claims (American Immigration Council 2015). But as importantly, the human rights of these children are at stake at each point of their migration. Social workers throughout the United States have found themselves ill prepared to address the rights of children who are caught up in detention systems or placed in foster or kin care.

This article addresses one aspect of irregular child migration to the United States - that of the right of the child to health, well-being, and rehabilitation particularly when held in US detention. The United Nations Committee against Torture's General Comment No. 3 provides the legal basis for the right to rehabilitation, defining rehabilitation as "the restoration of function or the acquisition of new skills... It seeks to enable the maximum possible self-sufficiency and function for the individual concerned, and may involve adjustments to the person's physical and social environment. Rehabilitation for victims should aim to restore, as far as possible, their independence, physical, mental, social and vocational ability; and full inclusion and participation in society" (UNCAT 2012, par. 11). This right is entwined with the right to the highest attainable standard of physical and mental health elaborated in a number of human rights treaties, including the UN Convention on the Rights of the Child. ${ }^{1}$ It is a critical obligation that has implications in the United States for federal, state, and local government, as well as, importantly, the social work profession.

\section{Scope of Child Migration and Response}

The US Customs and Border Patrol reported that they encountered 182,791 unaccompanied migrant children (aged 0-17) from the Northern Triangle countries (i.e., Guatemala, Honduras, and El Salvador) and Mexico along the Southwest border between fiscal years 2009 and 2014 (DHS-CBP, n.d.[a]). This included over 68,000 in fiscal year 2014 , representing a $90 \%$ increase of unaccompanied children who migrated to the United States over the Mexico border between 2013 and 2014 (Migration Policy Institute n.d.). More than 50,000 of these migrant children were from Central American countries where the incidence of violence often surpassed that found in war zones (LIRS 2015a). The migrants included greater representation of younger children and girls compared to previous years (LIRS 2015a), populations at particular risk of sexual violence.

Central American children have been treated differently by the US government than children from Mexico (Podkul et al.

\footnotetext{
${ }^{1}$ See also, the International Covenant on Economic, Social and Cultural Rights, 1966, Art. 12; CESCR General Comment No. 14 (UN Committee on Economic, Social and Cultural Rights 2000); the UN Convention on the Rights of the Child, 1989, Art. 24; and CRC General Comment No. 15, UN Committee on the Rights of the Child (2013, April 17).
}

2015). In comparison to Mexican children who have been rapidly deported in large numbers, children from Central America have disproportionately been allowed to apply for asylum (National Network for Immigrant and Refugees Rights n.d.). ${ }^{2}$ The United Nations High Commissioner for Refugees (UNHCR) expressed concern over the situation of Central American children and families in 2014, urging "all countries in the region to adopt a robust humanitarian response based on fundamental protection principles. This response should include efforts to address the root causes of this movement; to prevent and respond to human trafficking; and to meet the needs of those children who may be victims of persecution or torture" (UNHCR 2014b, par. 1).

The responsibility for sheltering and providing for the needs of unaccompanied undocumented children in the United States has shifted over the years. Before the mid-1990s, unaccompanied children were detained in federal facilities. The US Supreme Court ruled in 1993 that detention of these children was unconstitutional (Reno v. Flores 1993). The Court held that the federal government must provide such children with more humane care, utilizing a network of shelter care. The US Office of Refugee Resettlement (ORR) assumed responsibility from the Immigration and Naturalization Service (INS) for the care of unaccompanied migrant children in 2002. ORR receives referrals from the Department of Homeland Security (DHS) and other federal agencies and places each child in the least restrictive facility deemed to be in keeping with best interests of the child (e.g., a shelter, group home or foster care, residential treatment facility, secure care facility, or other special needs care facility) (Office of Refugee Resettlement 2015). The ORR's Unaccompanied Alien Children's Program has provided care and custody to unaccompanied minors from Central America while their immigration cases were processed (deeming them to be particularly at risk for being trafficked, exploited, or otherwise abused) (Office of Refugee Resettlement n.d.). When possible, ORR seeks to reunite these children with relatives in the United States.

ORR reported that it received 57,496 new referrals of migrant undocumented children from DHS in fiscal year 2014 alone (Office of Refugee Resettlement n.d.). Some of these children came to the United States with a parent or other guardian, while others were unaccompanied. An unaccompanied child, as defined by UNHCR (2008), is any person under the age of 18 who has been "separated from both parents and

\footnotetext{
${ }^{2}$ For those already in the United States, a number of forms of immigration relief are available to prevent removal (deportation) for some migrant children. These include Deferred Action for Childhood Arrivals (DACA) program (for temporary relief from removal), asylum, Special Immigrant Juvenile Status (SIJS, a humanitarian form of relief available to noncitizen minors who were abused, neglected, or abandoned by one or both parents), $U$ visa (for victims of some crimes), $T$ visa (for victims of severe forms of human trafficking), or other humanitarian relief (American Immigration Council 2015).
} 
other relatives and [is] not being cared for by an adult who, by law or custom, is responsible for doing so" (p. 8). The number of unaccompanied Central American children who fled to the United States doubled every year from 2011 through 2014 (UNHCR 2014a). The flow slowed down in fiscal year 2015 but fiscal year 2016 has seen increased numbers again, with $106 \%$ more unaccompanied child migrants in the first two months of fiscal year 2016 compared to the same time period in the previous fiscal year (DHS-CBP, n.d.[b]). ORR worked to increase its capacity to house these migrant children. Even greater numbers of Mexican children came to the United States, yet the majority of those were summarily returned to Mexico within a couple of days rather than remaining in detention.

Since 2014, some migrant children were eventually granted legal status and/or released to sponsors. Others remain detained for weeks or months, awaiting adjudication of their cases. It is challenging to document the conditions of detention and length of stay for such children, in part because the United States has out-sourced to private contractors the administration of some family detention centers (Gruberg 2015).

Yet, detention of children is, in itself, a human rights violation under international law. The United Nations Committee on the Rights of the Child maintains that detention may only be used in specific and exceptional circumstances as a measure of last resort and for as short a time as possible (CRC 1989, Art. 37). Practices of detaining migrant children are being debated and critiqued in other countries as well, such as Canada (Kronick and Rousseau 2015), Australia (Dudley et al. 2012; Silove et al. 2007), and the European Union (Hodes 2010; Nebehay and Tagaris 2016). The Inter-American Court of Human Rights (IACrtHR) issued an opinion in 2014 concerning states' obligations regarding protections for migrant children. The IACrtHR clarified that states must use a rights-based approach and consider the protection and best interests of a child over concerns related to the child's migrant status or nationality (Inter-American Court of Human Rights 2014). Despite the fact that the United States does not participate in the Inter-American Court, the principles are still applicable in the United States.

The UNHCR (2012) has clear guidelines regarding the detention of asylum seekers, calling for the fundamental right of freedom of movement and emphasizing that detention is inherently inappropriate for asylum seekers. Many international bodies advocate for alternatives to detention for all migrant children in keeping with international standards (Podkul et al. 2015). In July and August, 2015, a federal judge in California ordered the US government to release detained immigrant children in line with the 1985 Flores decision that requires minimum standards for detention, release, and treatment of children who have been detained (Harris 2016). The ruling in Flores $v$. Johnson (2015) applies to unaccompanied children and children detained with a parent or guardian. Following the decision, the DHS filed an appeal with the Ninth Circuit Court of
Appeals, arguing that such protections should only be applied to unaccompanied children. ${ }^{3}$ The appeal is currently pending. It is notable that in February 2016 the American Academy of Child and Adolescent Psychiatry (AACAP) and the National Association of Social Workers (NASW) (2016) filed an amicus curiae brief regarding the rights of detained child migrants. In the brief, these organizations underscored that "Immigration detention poses a severe risk to the mental health of minors, whether they are detained with or without their parents" (2016, p. 2). NASW emphasized its concern about children's human rights at stake in this case:

NASW supports efforts to ensure that children of immigrant families, regardless of citizenship status, are subject to the same societal protection as children from nonimmigrant families. As social work practitioners and proponents of human rights, NASW advocates for the protection of vulnerable people and condemns policies, practices, and attitudes of bigotry, intolerance, and hate that put human rights in jeopardy. NASW also supports the U.S. government in its methods of providing homeland security and combating terrorism that are consistent with human rights, values and ethics. The struggle to protect human rights remains a vital priority for the social work profession in the 21 st century. (Emphasis added, 2016, pp. 1-2)

\section{Background on Rights Violations Experienced by Detained Central American Child Migrants}

Whether accompanied or unaccompanied, the rights of migrant children in detention in the United States are being violated on a large scale (Terrio 2015). Child migrants, particularly those who do not have legal counsel, often have been deprived of having a voice in their own fate. Their detention has sometimes been framed as a protective measure (Human Rights Watch 2015b, May 15; Kronick and Rousseau 2015). The UNHCR (2014a) has described detention of children as needlessly restricting their liberty, impeding access to international protection such as asylum, and as "a tool to illegitimately discourage a child from seeking international protection" (p. 51).

\footnotetext{
${ }^{3}$ In January 2016, the Department of Human Services in Pennsylvania revoked the license of the Berks County Residential Facility in Pennsylvania and Berks appealed (Benshoff 2016). Berks was one of the three immigrant family detention centers in the United States. At the time of this writing, the appeal is pending. In Texas, concerted advocacy and public testimony from diverse grassroots organizations are fighting the plan by the Texas Department of Family and Protective Services to relicense two private detention facilities (run in cooperation with the Department of Homeland Security's Immigration and Customs Enforcement) as residential centers for undocumented children (Hoffberger 2015).
} 
In 2015, the Lutheran Immigration and Refugee Service (LIRS) (2015a) identified a number of key gaps in protection for unaccompanied migrant children, including the following: the flawed screening process at the border, which excludes many children from protection on the basis of nationality rather than individual circumstances; the use of inappropriate holding and institutional facilities both at the border and upon subsequent transfer; weaknesses in the system of placement, reunification, and follow-up that fail to fully ensure children's safety; the clear inadequacy of legal representation for children (despite heroic volunteer efforts); and budget-driven imperatives to fast-track procedures for children (p. 7).

LIRS (2015a) also called attention to a number of processes or forms of treatment by the US government or those the government has contracted that reflect human rights violations. These violations were identified in a number of states and facilities. LIRS cites the "disparate and discriminatory two-tiered screening process at the border based on nationality rather than child protection, and dependent upon interviews with children by enforcement agents rather than child welfare specialists" as key concerns (2015a, p. 20). They challenge the practice of using border detention cells for initial holding followed by detention in large institutional facilities "as the primary care and custody approaches with children." Moreover, they cite the immigration enforcement system's lack of a coordinated and comprehensive child welfare approach, including following guidelines for placement, reunification, and monitoring. LIRS also notes that children generally lack adequate legal representation and assistance from child advocates crucial to assuring their due process rights. And, finally, LIRS cites "intentional fast-tracking of legal procedures for children, despite their vulnerability and need for more time to build trust and case preparation" as a core concern (2015a, p. 21).

Migrant children who were not apprehended at a US border similarly face a wide range of harms in the United States, including forcible separation from parents and other family members; fear of being deported or of having one's parent(s) deported; risk of neglect or abuse within detention, other congregate or foster care (Planas 2015); and vulnerability to being trafficked.

Perhaps this is not surprising, given the significant failure to protect the rights of US-born children of undocumented immigrants (Bhabha 2006). Despite the promise of equal protection under the law for all citizens provided in the US Constitution, more than four million US citizen children of undocumented immigrants do not always receive this protection (Zayas and Bradlee 2014). Many such children have had their parents deported or live in fear that their parents will be deported. Some of those left behind in the United States are entrusted to the care of the state to be raised in foster care. Others are forced into exile in order to stay with their parents. Zayas (2015) has extensively documented the impact of US immigration policies on children, including an undermining of their rights, the infliction of significant long lasting trauma, and substantial harm to their mental health and well-being.

\section{Immigration Policies}

Current immigration laws in the United States are restrictive, emphasizing deportation rather than legalization, and have the effect of making some persons "illegal" and exacerbating inequalities in society (Dreby 2015). Contemporary policies that criminalize immigration are rooted in the Immigration Reform and Control Act of 1986, which initiated new programs to "screen individuals in federal, state, or local prisons and jails for removability" (Ewing et al. 2015, p. 14). Punitive tendencies were reinforced by the Illegal Immigration Reform and Immigrant Responsibility Act of 1996 (IIRIRA) and were sharpened further following the terrorist attacks of September 11, 2001 (Ewing et al. 2015). In 2005, the Bush Administration introduced Operation Streamline, which tries up to 80 immigrants at a time, helped to reinforce policies that violate basic due process rights under the US Constitution as well as international human rights norms. Operation Streamline represented a retrogressive policy turn which is still being challenged in US courts and through advocacy. Thus, child migrants, whether accompanied by family members or traveling on their own, face extraordinary challenges.

\section{Impact of Trauma on Unaccompanied Minors}

Many of the unaccompanied minors who have come to the United States in recent years already have experienced significant trauma in their homelands and/or during their migration experience. Among these experiences are the following: chronic physical, sexual, and/or psychological abuse at the hands of family members or others; witnessing severe domestic violence; forced labor; violence and/or death threats from gangs or drug traffickers; human trafficking; war; torture; loss of loved ones; homelessness and/or lack of access to basic needs; dangerous migration experiences; separation from family; and uncertainty about the future (National Child Traumatic Stress Network n.d.; UNHCR 2014a). The impact of these earlier traumas can be exacerbated by forced exile and by detention in the United States, resulting in long-lasting negative effects on the well-being of these children and their families (see the special issue of Forced Migration Review 2013). A systematic review of ten studies that examined the mental health impact of immigration detention on children, adolescents, and adults found high rates of mental health problems in all age groups (Robjant et al. 2009). In particular, detainees suffered from posttraumatic 
stress disorder (PTSD), depression, anxiety, suicidal ideation, and self-injurious behavior. The severity of distress was positively associated with length of time in detention. While impacted by methodological limitations, the studies provided some evidence that detention may contribute an independent adverse impact on mental health. Examination of the impact of detention on asylumseeking children and adolescents in the European Union similarly found high rates of PTSD, affective (mood) and anxiety disorders, and deliberate self-harm (Hodes 2010).

Detained children are at fragile stages of their development. Younger children in particular have less developed cognitive ability to make sense of or understand what is happening to them. This challenge can be especially pronounced when they or their families are deprived of adequate access to legal representation, a situation that frequently exacerbates their psychological distress (AACAP \& NASW 2016).

In addition to mental health effects, the physical health of detained migrant children may be at risk. Despite the provision of health and mental health screening, the health of detained migrant children is imperiled when there is a systematic lack of adequate access to health care and sanitary conditions in detention and upon release (National Immigration Law Center 2014; Preston 2015). Significant state-by-state differences remain. Despite the strengths and resilience that these children and their families may possess, the conditions and policies affecting migrant children can serve to compromise their functioning, well-being, and realization of their rights. Resources have been developed in the United States to assist migrant children and their families (Bridging Refugee Youth and Children's Services 2016; National Child Traumatic Stress Network n.d.). The Bridging Refugee Youth and Children's Services (BRYCS, a service of the US Conference of Catholic Bishops) has been designated as a Technical Assistance Provider for newcomer families and their providers by ORR. ${ }^{4}$

\section{The Right to Health, Well-Being, and Full Rehabilitation}

In the face of compromised health and well-being experienced by detained child migrants in the United States, the need to promote the realization of their rights to health, well-being, and rehabilitative services is great. It is essential that detained migrant children are able to access comprehensive person-centered rehabilitative services that will, in turn, facilitate the realization of their right to health. While such services could be offered while in

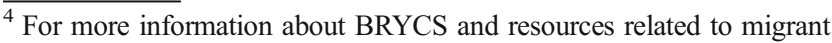
children and families, see: http://www.brycs.org/.
}

detention, a just approach to implementing the right to rehabilitation and health would necessitate an entirely different approach. Rather than be subject to forced residence in detention centers, in which children cannot participate in the everyday activities that foster resilience, inclusion, and well-being, detained migrant children should be integrated into community settings. This would entail different approaches depending upon situation- to be released to kin, placed in foster care, or supported with an accompanying family member until the child's status can be determined.

An interdisciplinary holistic approach that addresses the multifaceted effects of the harm and addresses the physical, psychological, social, and legal service needs of migrant children is required. It must be grounded in a bio-psycho-socialspiritual-cultural approach to promoting health (American Psychological Association 2010). Services also should be provided to family and guardians, including psycho-education to enable them to better understand what their children are going through and support them. Forensic medical and/or psychological evaluations, reports, and testimony may be needed, such as in cases of asylum or other legal proceedings. Training of local providers and organizations who are points-of-first-contact for child migrants and their caregivers can be valuable regarding their rights, signs of distress, and intervention strategies. Such organizations include public health/primary care clinics, emergency/urgent care, community-based organizations, refugee resettlement organizations, social services, and governmental organizations. Successful and ongoing coordination of care is vital. With appropriate health and rehabilitation services and coordinated care, traumatized child migrants have a better chance of recovering from the harmful effects of their experiences and successfully rebuild their lives.

\section{International Human Rights Principles Informing the US Case}

International human rights and humanitarian law has clearly articulated the rights issues that apply to children who have crossed national borders and are caught up in detention systems, such as in the United States. The United States has ratified only a handful of these treaties, including the Convention Against Torture and Other Cruel, Inhuman or Degrading Treatment or Punishment (CAT 1984), the International Covenant on Civil and Political Rights (ICCPR 1966), and the International Convention on the Elimination of All Forms of Racial Discrimination (1965). The United States has not joined two important treaties - the Convention on the Rights of the Child (CRC 1989) and the Convention on the Protection of the Rights of All Migrant Workers and 
Members of Their Families (1990). ${ }^{5}$ These treaties and corresponding UN documents, and extant US law (e.g., Flores v. Meese [1997] and Flores v. Johnson [2015]), provide a strong basis supporting the principle that undocumented children who are taken into custody in the United States should not be held in detention. But, without concerted advocacy and monitoring, the practice will likely persist. ${ }^{6}$

The UNHCR, in its work on detention practices, highlights a near prohibition on detention of children (whether accompanied or unaccompanied by family members), underscoring that "Overall an ethic of care - and not enforcement—needs to govern interactions with asylum-seeking children, including children in families, with the best interests of the child a primary consideration" (emphasis in the original, UNHCR 2012, par. 52). UNHCR stipulates that governments must work within child protection frameworks and use "appropriate procedures for the determination of the child's best interests, which facilitate adequate child participation without discrimination." Importantly, regarding the child's right to participation, the "views of the child" must be considered "in accordance with age and maturity, where decision makers with relevant areas of expertise are involved, and where there is a balancing of all relevant factors in order to assess the best option" (UNHCR 2012, par. 52).

This assessment is grounded in guiding principles outlined in the 1989 UN Convention on the Rights of the Child. That treaty, which the US has yet to ratify, has near universal standing and respected professional organizations within law, health, and social work in the United States utilize these principles in practice. Article 37 of the CRC outlines that governments must ensure that

1. No child shall be subjected to torture or other cruel, inhuman or degrading treatment or punishment ...

2. No child shall be deprived of his or her liberty unlawfully or arbitrarily. The arrest, detention, or imprisonment of a child shall be in conformity with the law and shall be used only as a measure of last resort and for the shortest appropriate period of time;

\footnotetext{
$\overline{5}$ As a sign of the pressing nature of the rights of migrant children at all stages of the migration process, in 2016 the UN Committee on the Protection of the Rights of All Migrant Workers and Members of Their Families and UN Committee on the Rights of the Child (n.d.) are drafting a Joint General Comment on the Rights of the Child in the Context of International Migration. This General Comment amplifies attention given to the rights of migrant children outlined in the UN Committee on the Rights of the Child General Comment No. 6 (2005), and the UN Human Rights Council Resolution on the "Human Rights of Migrants: Migration and the Human Rights of the Child" (2009).

${ }^{6}$ See Human Rights Watch (2015a, July 27). Following Flores v. Johnson (2015) in which a Federal District Judge ruled that it was unlawful to detain children and mothers, the US government is required to fully implement the recommendations of the Federal District Judge, including prohibiting detention of minors in secure facilities (see AILA 2015).
}

3. Every child deprived of liberty shall be treated with humanity and respect for the inherent dignity of the human person, and in a manner which takes into account the needs of persons of his or her age...;

4. Every child deprived of his or her liberty shall have the right to prompt access to legal and other appropriate assistance, as well as the right to challenge the legality of the deprivation of his or her liberty before a court or other competent, independent and impartial authority, and to a prompt decision on any such action (CRC, 1989, emphasis added).

\section{The Convention on the Rights of the Child and Links to the Right to Rehabilitation and Health}

The 2013 CRC General Comment No. 15 on the right of the child to the highest attainable standard of health provides substantive guidance to governments on their obligations to respect, protect and fulfill this right. Despite the US failure to ratify the CRC, domestic human rights advocates, lawyers, social workers, doctors, and judges have increasingly cited the treaty standards related to children. General Comment No. 15 frames a right to rehabilitation and services for children who are experiencing "mental ill-health," underscoring the need for a broad range of psycho-social approaches. The document underscores, "States have the obligation to provide adequate treatment and rehabilitation for children with mental health and psychosocial disorders while abstaining from unnecessary medication" (2013, April 17, par. 38). Specific guidance on a right to rehabilitation and health care related to migration emphasizes the "need to recognize the particular challenges to children's health for children affected by humanitarian emergencies, including those resulting in large-scale displacements due to natural or man-made disasters." General Comment No. 15 stresses that governments must take "all possible measures" to ensure children's "uninterrupted access to health services, to (re)unite them with their families and ... to encourage special parental or other psychosocial care to prevent or address fear and traumas" (2013, April 17, par. 40, emphasis added). The guidance on health and wellbeing is particularly instructive for the US case.

Additionally, a 2012 Day of General Discussion sponsored by the Committee on the Rights of the Child focused on "The Rights of All Children in the Context of International Migration." Those who provided expert input and testimony during the Day of General Discussion underscored that mental health and healthcare services were critical to the well-being of child migrants. The Committee (2012) recommended: "States should ensure and implement adequate and accessible measures for addressing trauma experienced by children during migration, asylum-seeking or trafficking. Special care should be taken to make mental health services available to 
all children, including in the context of conducting the child's best interests assessment, evaluation and determination" (par. 89).

Of special interest to social workers, who may be called upon to work in detention facilities or provide assessments of children for immigration court services, are the obligations of "third party" or "nonstate" actors in respecting migrant children's rights. General Comment No. 6 (2004), Treatment of Unaccompanied and Separated Children Outside Their Country of Origin, is an important resource for developing rights-based approaches to working with children who are not accompanied by a parent (UN Committee on the Rights of the Child 2005). The standards, while focused on unaccompanied minors, are relevant for children who may be detained with parents as well.

Children "deprived of their family environment" are entitled to special protection and care by the state (and any third party actors acting on the state's behalf). Alternate care should adhere to specific guidelines summarized here. International guidelines for alternate care provide a useful framework for US practice as well. According to these principles, children "should not, as a general rule, be deprived of liberty" (UN Committee on the Rights of the Child 2005, par. 40) and the "best interests of the child" must be adhered to when considering "changes in residence." In addition, to promote the principle of "family unity," siblings should not be separated. Family reunification in the country of asylum should be promoted, "unless such action would be contrary to the best interests of the child." The guidelines mandate that social workers should conduct "regular assessments" to ensure the "child's physical and psychosocial health, protection against domestic violence or exploitation, and access to educational and vocational skills and opportunities." And, importantly in the context of the US case, even in emergency situations, "interim care must be provided for the shortest time appropriate for unaccompanied children" and such care must provide for children's "security and physical and emotional care in a setting that encourages their general development" (par. 40). Finally, in accordance with principles to facilitate participation of children in decisions that affect them, children must be kept informed of the care arrangements being made for them, and their opinions must be taken into consideration. These provisions are consonant with the NASW Code of Ethics (2008) and have significant implications for social workers. For example, social workers should advocate with immigration judges, those administering detention facilities, and other relevant decision makers to ensure that the best interest of the child is paramount in all decisions about care arrangements. Social workers should remain vigilant in their ongoing assessments to ensure that state actors and private contractors do not abuse, neglect or otherwise exploit migrant children.

\section{Convention against Torture and Other Cruel, Inhuman, or Degrading Treatment or Punishment}

While most of the child migrants fleeing to the United States have not experienced torture, the conditions these children are subjected to in US detention has been defined as amounting to cruel, inhuman, or degrading treatment or punishment. In his report to the UN Human Rights Council, Juan Mendez, the UN Special Rapporteur on torture and other cruel, inhuman or degrading treatment or punishment, identified the lack of appropriate state oversight and basic resources as key sources of ill-treatment of detained migrant children, and pointed to the need for independent and regular monitoring of detention centers. Leaving no question regarding his stand on the detention of migrant children, Mendez stated that immigration detention practices globally "put children at risk of cruel, inhuman or degrading treatment or punishment" (UN General Assembly 2015, p. 17). He underscored that "the detention of children who migrate to escape exploitation and abuse contravenes the duty of the State to promote the physical and psychological recovery of child victims in an appropriate environment." Thus, governments (like the United States) "should, expeditiously and completely, cease the detention of children, with or without their parents, on the basis of their immigration status" (UN General Assembly 2015, p. 17). Mendez recognized the particular vulnerability of children to torture and ill-treatment relative to adults as well as states' obligations to protect children from such abuses and act in their best interests. He urged the authorities to implement alternatives to detention, reserving detention as a last resort in exceptional cases. The effects of detention on the health and well-being of children often is far reaching. Mendez (2014) has also denounced the use of solitary confinement of any duration for children. It is essential that the right of these children to health and rehabilitation is protected and facilitated.

It is still uncommon for the UN Committee against Torture's right to rehabilitation standard to be invoked vis-avis the rights of child migrants. As a party to CAT, the United States is obliged to implement standards elaborated in the General Comment No. 3. In particular, the document specifies that "rehabilitation for victims should aim to restore, as far as possible, their independence, physical, mental, social and vocational ability; and full inclusion and participation in society" (UN CAT 2012, Sec. 11). In keeping with CAT, those grappling with responding to the crisis of migrant children must stop detaining children and ensure that they are provided with full inclusion in society and rehabilitation. Providing rehabilitation in detention is antithetical with the concept of full rehabilitation. 


\section{Recommendations}

There have been some changes in US policy regarding detained migrant children and families in recent months. Much comes in the wake of growing public pressure and the recent Flores v. Johnson (2015) ruling that mandates a reduction in the length of detention for children and mothers (Preston 2015) and a July 13 decision by the Obama administration to release migrant mothers and their children from detention if they have been found by the DHS to have fled their homeland due to a credible fear for their lives (LIRS 2015b). Despite these developments, the rights of these vulnerable migrants to health and rehabilitation are not robustly or systematically protected. While the ORR promotes the housing of migrant children in the least restrictive environment, implementation of this principle has been uneven and compromised. Detention of children for four or five weeks, or for any length of time, is still too long (AACAP \& NASW 2016).

There is a continued vital need for advocacy, monitoring, and transparency, particularly since such standards are often aspirational and not met. For example, ORR began to place unaccompanied migrant children with sponsors as they awaited their immigration hearings but they failed to systematically track the children's well-being or maintain sufficient case records or oversight (US Government Accountability Office 2016). While undocumented children in some parts of the country were able to access health care, others experienced barriers to such care due to lack of health insurance or knowledge of where to seek services, lack of bilingual community services, and/or fear of the consequences of revealing their immigration status (GAO 2016). In some cases, a US Senate investigation found that migrant children had been subjected to human trafficking or other abuse (Ryan 2016).

In this article, we have argued that such children (and their families) have a right to health, well-being, and rehabilitation. This right applies to all human beings, regardless of age and legal status. We highlight several recommendations here:

- The United States should take steps to ensure that all child migrants in (and outside of) detention have access to appropriate health care and rehabilitative services.

- The United States should work to ensure that child migrants are not detained, but are provided with community-based alternatives such as those promoted by LIRS (2015a).

- Solitary confinement of child migrants in detention must be prohibited.

- The Office of Refugee Resettlement and its programming partners should prioritize child protection and safety in reunification decisions by revising assessment tools, improving collaboration, and preparing children and families for successful reunifications (LIRS 2015a).
- Child migrants should be able to attend public school with no barriers to entrance and should also be able to participate in programs that further their health and well-being, such as the School Lunch Program, bilingual education, and special education. This may be as important as intensive therapeutic work for many children in order to provide a sense of normalcy and well-being. Education is also a human right which enables the enjoyment of other human rights (CRC, Art. 28; CMW, Art. 30). ${ }^{7}$

- Access to legal counsel and to health, mental health, and social services is critical to child well-being. This includes supports for child migrants who have experienced violence during transit and at centers, including sexual violence.

- A substantial increase in funding for health care and programs focusing on rehabilitation is required for the United States to fulfill the substantive requirements of the right to health and rehabilitation and promote the ability of child migrants and their families to live productive lives of dignity.

- Appropriate, regular, and full oversight by independent monitors for detention centers in which children are held.

While these recommendations apply to a wide range of actors (e.g., ORR policy makers, the Office of Homeland Security, officials in federal and state Health and Human Services departments, lawyers, judges, and a range of health care providers), social workers bear a particular onus to understand and recognize such principles in their advocacy and practice. Thus, it is incumbent social work practitioners and educators to not only become informed about this issue, but also to become involved in collective efforts to advocate for the rights of migrant children. Social work scholar-practitioners, such as Luis Zayas, have led the profession in terms of providing mental health assessments and treatment, documentation of the effects of detention on children for the courts, and in their classrooms and in advocacy at local, state and national levels (Zayas 2015; Zayas and Bradlee 2014). Forming a well-defined network of such social workers and educators across the country could facilitate much wider recognition of and advocacy on this and other related immigrant rights issues in the United States.

Whistle-blowers, such as Olivia Lopez, a social worker formerly employed at Karnes County Residential Center in Texas where migrant mothers and children were detained, are crucial actors in promoting policy change. Lopez testified about the treatment of detained migrants at a forum on family

\footnotetext{
${ }^{7}$ Article 30 of the Migrant Workers Convention states that "Each child of a migrant worker shall have the basic right of access to education on the basis of equality of treatment with nationals of the State concerned. Access to public pre-school educational institutions or schools shall not be refused or limited by reason of the irregular situation with respect to stay or employment of either parent or by reason of the irregularity of the child's stay in the State of employment."
} 
detention at the US House of Representatives (Lopez 2015). Lopez exposed practices at Karnes, such as separating children from their mothers, as amounting to child abuse (Democracy Now! 2015, July 29). Yet, to effect widespread change in this system that has largely failed migrant children to date, a much broader investment by social workers and professional institutions such as the Council on Social Work Education and the National Association of Social Workers is also needed. This would include partnering with legal and immigrant rights groups, such as the American Immigration Lawyers Association, at state and national levels to investigate government failures to secure children's rights; developing rights-based practices within public and private institutions serving migrant children (whether in detention or the child welfare system); and legislative advocacy at state and national levels. Recent calls for suspending or severely restricting the admittance of refugees following violence attributed to terrorists, a few of whom were reported to have been refugees, underscores the need for this advocacy.

To effect such change, we must imagine an entirely different approach. This vision is summarized effectively in testimony provided by Luis Zayas at a 2015 Congressional forum on Family Detention. Zayas outlines an approach ${ }^{8}$ grounded in the human rights principles discussed above: "We need village-like environments that resemble communities, not prisons. They should be operated by capable licensed nonprofit social service and child welfare agencies using evidence-based best practices. Staff should be counselors and advisors, case managers and aides" (as cited in Seda 2015). He highlights that social workers should be involved in "conducting psychosocial evaluations and assessing family needs, and making connections to clinics, schools, churches, non-profit groups, and government agencies in their destination cities." Zayas also encourages engaging law students and social work interns to lead groups to help mothers and children to understand the US legal, school, and healthcare systems.

What would it mean for social workers - practitioners and educators - to take up Zayas' call above? A small number of collaborations between social work and law have been developed across the country. ${ }^{9}$ This model could be expanded, affording stronger collaborations between lawyers and social workers (or interns from both professions) to help realize the goal of timely, just, and effective integration within communities. Zayas' testimony also resonates with best practices learned at the University of Connecticut Law School's

\footnotetext{
${ }^{8}$ Excerpted from Congressional testimony by Dr. Luis Zayas (Dean, School of Social Work, University of Texas at Austin) at the Family Detention Forum on July 28, 2015 (See Seda 2015).

${ }^{9}$ Collaborations exist, for example, in Connecticut (at the University of Connecticut), in Los Angeles (with Public Council Inc. and the Legal Aid Foundation of Los Angeles), and in Chicago (the Young Center for Immigrant Children's Rights at the University of Chicago).
}

Asylum and Human Rights Clinic to foster interprofessional teams that coordinate responses to asylum seekers' situations. Such teams include lawyers, social workers doing both micro and macro practice activities, psychiatrists, and doctors, and involve outreach to community-based organizations. We recommend as well, adapting this approach to immigration law clinic settings and other community-based organizations working on behalf of immigrant children's rights, particularly with respect to the right to rehabilitation and healthcare.

As a profession we must develop a socially responsive, just child welfare system that supports the rights of undocumented children rather than (knowingly or unwittingly) participating in systems that violate their rights (Colvin 2014). Drawing upon rights-based standards elaborated above, we call for the fullest engagement by the social work profession in challenging current detention practices and developing adequate resources and supports to realize the rights of migrant children to health and well-being regardless of immigration status.

\section{References}

American Immigration Council. (2015). A guide to children arriving at the border: laws, policies and responses. Retrieved from http:// immigrationpolicy.org/specialreports/guide-children-arrivingborder-laws-policies-and-responses

American Immigration Lawyers Association, American Immigration Council, Catholic Legal Immigration Network, Inc., \& Raices (AILA). (2015). The Flores litigation and the impact on family detention. Retrieved from http://immigrationpolicy.org/sites/ default/files/docs/The $\% 20$ Flores $\% 20$ Litigation $\% 20$ and $\% 20$ the $\%$ 20Impact $\% 20$ on\%20Family\%20Detention.pdf

American Psychological Association. (2010). Resilience and recovery after war: refugee children and families in the United States. Washington, DC: Author. Retrieved from https://www.apa.org/ pubs/info/reports/refugees-full-report.pdf

Benshoff L. (2016). Berks detention center still holding undocumented families, thanks to appeal. Newsworks. Retrieved from http://www. newsworks.org/index.php/local/pa-suburbs/91179-berks-detentioncenter-still-holding-undocumented-families-thanks-to-appeal

Brief for the American Academy of Child and Adolescent Psychiatry (AACAP) and the National Association of Social Workers (NASW) as Amici Curiae Supporting Appellees, Flores v. Lynch. (2016) (no. 15-56434). Retrieved from http://www. humanrightsfirst.org/sites/default/files/HRFFloresAmicusBrief.pdf

Bhabha, J. (2006). The child—what sort of human? PMLA, 121(5), $1526-35$

Bridging Refugee Youth and Children's Services. (2016). Promising practices. Retrieved from http://www.brycs.org/promisingPractices/ index.cfm

Colvin, M. (2014). The devolution of immigration enforcement policy and child welfare practice. Journal of Policy Practice, 13(1), 16-29.

Department of Homeland Security, U.S. Customs and Border Protection [DHS-CBP]. (n.d.[a]). Southwest border unaccompanied alien children statistics FY. (2014). Retrieved from http://www.cbp.gov/ newsroom/stats/southwest-border-unaccompanied-children/fy-2014

Department of Homeland Security, U.S. Customs and Border Protection [DHS-CBP]. (n.d.[b]). Southwest border unaccompanied alien 
children statistics FY. (2016). Retrieved from http://www.cbp.gov/ newsroom/stats/southwest-border-unaccompanied-children/fy-2016

Democracy Now! (2015). This is child abuse: Social worker breaks silence over conditions inside immigrant detention center. Retrieved from http://www.democracynow.org/2015/7/29/this is child abuse_social_worker

Dreby, J. (2015). Everyday illegal: When policies undermine immigrant families. Oakland: University of California Press.

Dudley, M., Steel, Z., Mares, S., \& Newman, L. (2012). Children and young people in immigration detention. Current Opinion in Psychiatry, 25(4), 285-292.

Ewing, W. A., Martínez, D. E., Rumbaut, R. G. (2015). The criminalization of immigration in the United States: A special report. American Immigration Council. Retrieved from http://immigrationpolicy.org/ special-reports/criminalization-immigration-united-states

Flores v. Meese (1997). Flores Settlement, Case \# CV-85-4544 (C.D. Cal. 1997). Retrieved from http://web.centerforhumanrights.net:8080/ centerforhumanrights/children/Document.2004-06-18.8124043749

Flores v. Johnson (2015). Case No. CV 85-4544 DMG (AGRx) (July 24, 2015). Retrieved from http://graphics8.nytimes.com/packages/pdf/ us/FloresRuling.pdf

Forced Migration Review. (2013). Special issue: Detention, alternatives to detention, and deportation. Forced Migration Review, 44. Retrieved from http://www.fmreview.org/detention

Gruberg, S. (2015). How for-profit companies are driving immigration detention policies. Center for American Progress. Retrieved from https://cdn.americanprogress.org/wp-content/uploads/2015/12/ 17121556/ForProfitDetention-briefDec.pdf

Harris, L. (2016). Amicus arguments at the Ninth Circuit: The Flores settlement applies to all children. Immigration Impact. Retrieved from http://immigrationimpact.com/2016/02/26/amicus-argumentsat-the-ninth-circuit-the-flores-settlement-applies-to-all-children/

Hodes, M. (2010). The mental health of detained asylum seeking children. European Child and Adolescent Psychiatry, 19(7), 621-623.

Hoffberger, C. (2015). Speakers testify against detention facility relicensing: Instead of changing conditions, DFPS plans to just change detention center classification. The Austin Chronicle. Retrieved from http://www.austinchronicle.com/news/2015-12-18/ speakers-testify-against-detention-facility-relicensing/

Human Rights Watch. (2015a). US: Release detained migrant children, mothers: Federal court rejects administration's family detention policy. Retrieved from https://www.hrw.org/news/2015/07/27/usrelease-detained-migrant-children-mothers

Human Rights Watch. (2015b). US: Trauma in family immigration detention. Retrieved from https://www.hrw.org/news/2015/05/15/ us-trauma-family-immigration-detention-0

Inter-American Court of Human Rights (IACrtHR). (2014). Advisory Opinion OC-21/14, "Rights and Guarantees of Children in the Context of Migration and/or in Need of International Protection", OC-21/14. Retrieved from http://www.refworld.org/docid/ $54129 \mathrm{c} 854 . \mathrm{html}$

Kronick, R., \& Rousseau, C. (2015). Rights, compassion and invisible children: a critical discourse analysis of the parliamentary debates on the mandatory detention of migrant children in Canada. Journal of Refugee Studies. Advance Online Publication. doi:10.1093/jrs/ fev005.

Lopez, O. (2015). Statement at Family Detention Forum, U.S. House of Representatives. Retrieved from http://democrats.judiciary.house. gov/press-release/progressive-caucus-house-judiciary-democratshold-forum-family-detention

Lutheran Immigration and Refugee Service (LIRS). (2015a). At the crossroads for unaccompanied migrant children: Policy, practice, \& protection. Retrieved from http://irs.org/crossroads/

Lutheran Immigration and Refugee Service (LIRS). (2015b). July 13, 2015 STATEMENT - LIRS welcomes announcement that immigrant families seeking refuge in the United States will not be detained. Press Release. Retrieved from http://lirs.org/pressinquiries/press-room/150713statement/

Mendez, J. (2014). Statement submitted to Senator Durbin for the purpose of the Second Congressional Hearing on Solitary Confinement on February 25, 2014; Reassessing Solitary Confinement II: The Human Rights, Fiscal, and Public Safety Consequences. Retrieved from http://antitorture.org/wp-content/uploads/2014/02/SpecialRapporteur-on-Torture-Submission-to-Second-CongressionalHearing-on-Solitary-Confinement.pdf

Migration Policy Institute. (n.d.). Rising child migration to the United States. Retrieved from http://www.migrationpolicy.org/programs/ us-immigration-policy-program/rising-child-migration-united-states

National Association of Social Workers (NASW). (2008). Code of ethics for social workers. Washington, DC: NASW.

National Child Traumatic Stress Network. (n.d.). Guidance for working with unaccompanied migrant children. Retrieved from http://nctsn. org/trauma-types/refugee-trauma/guidance-unaccompanied

National Immigration Law Center. (2014). Unaccompanied children and health care. Retrieved from www.nilc.org/document.html?id=1126

National Network for Immigrant and Refugees Rights (NNIRR). (n.d.) Migrant children crossing the U.S.-Mexico border. Retrieved from: http://www.nnirr.org/drupal/migrant-children

Nebehay, S. \& Tagaris, K. (2016). UNHCR says it won't work in Greek 'detention centers' in swipe at EU-Turkey deal. Reuters. Retrieved from http://www.reuters.com/article/us-europe-migrants-greeceunhor-idUSKCNOWO31Z

Office of Refugee Resettlement (ORR). (n.d.). About unaccompanied children's services. Retrieved from http://www.acf.hhs.gov/ programs/orr/programs/ucs/about\#overview

Office of Refugee Resettlement (ORR). (2015). Children entering the United States unaccompanied: Section 1. Placement in ORR care provider facilities. Retrieved from http://www.acf.hhs.gov/ programs/orr/resource/children-entering-the-united-statesunaccompanied-section-1\#1.3

Planas, R. (2015). Lawyers claim medical neglect at ICE family detention centers: Woman with broken bones told to "drink water," attorneys allege. The Huffington Post. Retrieved from http://www. huffingtonpost.com/entry/lawyers-demand-civil-rightsinvestigation-into-family-detention 55bbd5f6e 4b06363d5a240ab

Podkul, J., Katz, R., Kelsey, J., Center for Gender \& Refugee Studies, Universidad Nacional De Lanus, et al. (2015). Detention and treatment of unaccompanied migrant children and the U.S.-Mexico border. In Childhood and migration in Central and North America: Causes, policies, practices and challenges (pp. 357-382). San Francisco: Center for Gender \& Refugee Studies.

Preston, J. (2015). Judge orders release of immigrant children detained by U.S. New York Times. Retrieved from http://www.nytimes.com/ 2015/07/26/us/detained-immigrant-children-judge-dolly-gee-ruling. html? $\mathrm{r}=0$

Reno v. Flores (1993). 507 U.S. 292 (1993). Retrieved from https://www. law.cornell.edu/supct/html/91-905.ZO.html

Robjant, K., Hassan, R., \& Katona, C. (2009). Mental health implications of detaining asylum seekers: Systematic review. British Journal of Psychiatry, 194(4), 306-312.

Ryan, T. (2016). Senate grills White House on readiness for child migrants. Courthouse News. Retrieved from http://www. courthousenews.com/2016/02/23/senate-grills-white-house-onreadiness-for-child-migrants.htm

Seda, C. H. (2015). Dr. Luis Zayas provides testimony on family detention. Migrant Clinicians Network. Retrieved from http://www. migrantclinician.org/blog/2015/jul/dr.-luis-zayas-providestestimony-family-detention.html

Silove, D., Austin, P., \& Steel, Z. (2007). No refuge from terror: The impact of detention on the mental health of trauma-affected refugees seeking asylum in Australia. Transcultural Psychiatry, 44(3), 359393. 
Terrio, S. J. (2015). Whose child am I?: Unaccompanied, undocumented children in U.S. immigration custody. Berkeley: University of California Press.

United Nations. (1965). International convention on the elimination of all forms of racial discrimination. G.A. Res. 2106 (XX). Retrieved from http://www.ohchr.org/EN/ProfessionalInterest/Pages/CERD.aspx

United Nations. (1966). International covenant on civil and political rights. G.A. Res. 2200A (XXI). Retrieved from http://www.ohchr. org/Documents/ProfessionalInterest/ccpr.pdf

United Nations. (1984). Convention against torture and other cruel, inhuman or degrading treatment or punishment. G.A. Res. 39/46. Retrieved from http://www.ohchrorg/Documents/ ProfessionalInterest/cat.pdf

United Nations. (1989). Convention on the rights of the child. G.A. Res. 44/25. Retrieved from: http://www.ohchr.org/Documents/ ProfessionalInterest/crc.pdf

United Nations. (1990). Convention on the protection of the rights of all migrant workers and members of their families. G. A. Res. 45/158. Retrieved from http://www2.ohchr.org/english/bodies/cmw/cmw. htm

UN Committee Against Torture. (2012). General Comment No. 3, 2012: Convention against torture and other cruel, ilnhuman or degrading treatment or punishment: Implementation of Article 14 by States Parties. Retrieved from http://www.refworld.org/docid/5437cc274. html

UN Committee on the Protection of the Rights of All Migrant Workers and Members of Their Families \& UN Committee on the Rights of the Child. (n.d.). Joint General Comment on the Rights of the Child in the Context of International Migration: Concept Note. Retrieved from http://tbinternet.ohchr.org/_layouts/treatybodyexternal/ Download.aspx?symbolno $=\overline{C R C} / \mathrm{CMW} \% 20 \mathrm{Genera} \%$ 20Comment\&Lang=en

UN Committee on the Rights of the Child. (2013). General Comment No. 15 (2013) on the right of the child to the enjoyment of the highest attainable standard of health (Art. 24). Retrieved from http://www2. ohchr.org/english/bodies/crc/docs/GC/CRC-C-GC-15 en.doc.

UN Committee on the Rights of the Child. (2012). Report of the 2012 day of general discussion: The rights of all children in the context of International Migration. Retrieved from http://www2.ohchr.org/ english/bodies/crc/docs/discussion2012/2012CRC_DGDChildrens Rights InternationalMigration.pdf

UN Committee on the Rights of the Child. (2005). General Comment No. 6: Treatment of unaccompanied and separated children outside their country of origin. CRC/GC/2005/6, Retrieved from http://www2. ohchr.org/english/bodies/crc/docs/GC6.pdf

UN Committee on Economic, Social and Cultural Rights. (2000). CESCR General Comment No. 14: The right to the highest attainable standard of health (Art. 12). Adopted at the Twentysecond Session of the Committee on Economic, Social and Cultural Rights, on 11 August 2000 (Contained in Document E/ C.12/2000/4). Retrieved from http://www.refworld.org/docid/ 4538838d0.html

UN General Assembly. (2015). Report of the UN Special Rapporteur on torture and other cruel, inhuman or degrading treatment of punishment, Juan Ernesto Mendez. A/HRC/28/68. Human Rights Council, Twenty-eighth session, Agenda item 3. Promotion and protection of all human rights, civil, political, economic, social and cultural rights, including the right to development. Retrieved from http://www. ohchr.org/EN/HRBodies/HRC/RegularSessions/Session28/ Documents/A HRC 2868 E.doc

UN High Commissioner for Refugees, Regional Office for the United States and the Caribbean. (2014a). Children on the run: Unaccompanied children leaving Central America and Mexico and the need for international protection. Retrieved from http:// unhcrwashington.org/children

UN High Commissioner for Refugees (UNHCR). (2014b). UNHCR calls for Continued access to asylum procedures for children fleeing violence in Central America. Retrieved from http://www. unhcrwashington.org/media-news/press-releases/unhcr-callscontinued-access-asylum-procedures-children-fleeing-violence

UN High Commissioner for Refugees (UNHCR). (2012). Guidelines on the applicable criteria and standards relating to the detention of Asylum-Seekers and alternatives to detention. Retrieved from http://www.refworld.org/pdfid/503489533b8.pdf

UN High Commissioner for Refugees (UNHCR). (2008). UNHCR guidelines on determining the best interests of the child. Retrieved from http://www.refworld.org/docid/48480c342.html

UN Human Rights Council. (2009). Human Rights Council Resolution 12/6 -"Human Rights of Migrants: Migration and the Human Rights of the Child.” Retrieved from http://www2.ohchr.org/ english/issues/migration/consultation/docs/States/Portugal.doc

U.S. Government Accountability Office (GAO). (2016). Unaccompanied children: HHS can take further actions to monitor their care. GAO16-180. Retrieved from http://www.gao.gov/products/GAO-16-180

Wilson, M. (2014). Unaccompanied migrant children: Overview and recommendations. Social Justice Brief [Web log comment]. Retrieved from www.socialworkblog.org/wp.../Unaccompanied-MigrantChildren.pdf

Zayas, L. (2015). Forgotten citizens: deportation, children, and the making of American exiles and orphans. New York: Oxford University Press.

Zayas, L. H., \& Bradlee, M. H. (2014). Exiling children, creating orphans: when immigration policies hurt citizens. Social Work, 59(2), 167-175. 